\title{
Methyl Supplementation Attenuates Cocaine-Seeking Behaviors and Cocaine-Induced c-Fos Activation in a DNA Methylation-Dependent Manner
}

\author{
Katherine N. Wright, ${ }^{1}$-Fiona Hollis, ${ }^{1,2}$ - $F$ Florian Duclot, ${ }^{1}$ Amanda M. Dossat, ${ }^{1}$ CCaroline E. Strong, ${ }^{1}$ T. Chase Francis, ${ }^{3}$ \\ Roger Mercer, ${ }^{1}$ ○Jian Feng, ${ }^{4}$ ○David M. Dietz, ${ }^{5}$ Mary Kay Lobo, ${ }^{3}$ Eric J. Nestler, ${ }^{4}$ and Mohamed Kabbaj ${ }^{1}$ \\ ${ }^{1}$ Program in Neuroscience, Department of Biomedical Sciences, Florida State University, Tallahassee, Florida 32306, ${ }^{2}$ Federal Polytechnic School of \\ Lausanne, CH-1015 Lausanne, Switzerland, ${ }^{3}$ Department of Anatomy and Neurobiology, University of Maryland School of Medicine, Baltimore, Maryland \\ 21201, ${ }^{4}$ Fishberg Department of Neuroscience and Friedman Brain Institute, Icahn School of Medicine at Mount Sinai, New York, New York 10029, and \\ ${ }^{5}$ Department of Pharmacology and Toxicology, University at Buffalo, Buffalo, New York 14214
}

\begin{abstract}
Epigenetic mechanisms, such as histone modifications, regulate responsiveness to drugs of abuse, such as cocaine, but relatively little is known about the regulation of addictive-like behaviors by DNA methylation. To investigate the influence of DNA methylation on the locomotor-activating effects of cocaine and on drug-seeking behavior, rats receiving methyl supplementation via chronic $\mathrm{L}$-methionine (MET) underwent either a sensitization regimen of intermittent cocaine injections or intravenous self-administration of cocaine, followed by cue-induced and drug-primed reinstatement. MET blocked sensitization to the locomotor-activating effects of cocaine and attenuated drug-primed reinstatement, with no effect on cue-induced reinstatement or sucrose self-administration and reinstatement. Furthermore, upregulation of DNA methyltransferase $3 \mathrm{a}$ and $3 \mathrm{~b}$ and global DNA hypomethylation were observed in the nucleus accumbens core (NAc), but not in the medial prefrontal cortex ( $\mathrm{mPFC}$ ), of cocaine-pretreated rats. Glutamatergic projections from the mPFC to the NAc are critically involved in the regulation of cocaine-primed reinstatement, and activation of both brain regions is seen in human addicts when reexposed to the drug. When compared with vehicle-pretreated rats, the immediate early gene c-Fos (a marker of neuronal activation) was upregulated in the NAc and MPFC of cocaine-pretreated rats after cocaine-primed reinstatement, and chronic MET treatment blocked its induction in both regions. Cocaine-induced c-Fos expression in the NAc was associated with reduced methylation at $\mathrm{CpG}$ dinucleotides in the c-Fos gene promoter, effects reversed by MET treatment. Overall, these data suggest that drug-seeking behaviors are, in part, attributable to a DNA methylation-dependent process, likely occurring at specific gene loci (e.g., c-Fos) in the reward pathway.
\end{abstract}

Key words: addiction; c-Fos; cocaine; epigenetics; methionine

\section{Introduction}

Cocaine (COC) addiction is characterized by compulsive and pathological drug use despite negative consequences (Koob and Le Moal, 1997; Robinson and Berridge, 2003; Everitt and Robbins, 2005). Relapse is a major obstacle that many individuals with addiction face on their path to recovery (Simpson et al., 1999). As such, there is a critical need to gain better understanding of the neurobiological mechanisms of addiction and relapse

Received Dec. 23, 2014; revised May 6, 2015; accepted May 7, 2015.

Author contributions: K.N.W., F.H., F.D., J.F., D.M.D., M.K.L., E.J.N., and M.K. designed research; K.N.W., F.H., A.M.D., C.E.S., and R.M. performed research; F.D., T.C.F., R.M., J.F., D.M.D., M.K.L., and E.J.N. contributed unpublished reagents/analytic tools; K.N.W., F.H., F.D., and M.K. analyzed data; K.N.W. and M.K. wrote the paper.

This research was supported by National Institutes of Health Grants R01MH087583 and R01MH099085 (M.K.), R01DA037257 (D.M.D.), and P01DA008227 (E.J.N.). We thank Elsa Johnson and Samantha Pavlock for their technical assistance and Charles Badland for his help with constructing figures.

The authors declare no competing financial interests.

Correspondence should be addressed to Mohamed Kabbaj, Florida State University, College of Medicine, Department of Biomedical Sciences, 1115 West Call Street, Tallahassee, FL 32306. E-mail:mohamed.kabbaj@med.fsu.edu. DOI:10.1523/JNEUROSCI.5227-14.2015

Copyright $\odot 2015$ the authors $\quad 0270-6474 / 15 / 358948-11 \$ 15.00 / 0$ to improve treatments and reduce the likelihood of relapse. Epigenetic mechanisms regulate transcriptional changes that underlie long-lasting neuroadaptations occurring with chronic COC exposure (Kumar et al., 2005; Brami-Cherrier et al., 2009; Renthal et al., 2009; Maze et al., 2010; Robison and Nestler, 2011; Malvaez et al., 2013). DNA methylation, the addition of methyl groups onto the 5-position of cytosines by DNA methyltransferases (Dnmt1, Dnmt3a, Dnmt3b), is usually a repressive marker when occurring in close proximity to transcription start sites (Jones, 2012). Previously considered a static process in the adult CNS, DNA methylation dynamically regulates neural functions associated with synaptic plasticity and learning and memory (Szyf et al., 2005; Levenson et al., 2006; Miller and Sweatt, 2007; Nelson et al., 2008; Feng et al., 2010; Day et al., 2013). In fact, enhancing the pool of available methyl donors with $S$-adenosylmethionine (SAM) or its precursor, L-methionine (MET), increases DNA methylation and alters gene expression (Dong et al., 2008; Anier et al., 2010). Additionally, MET blocks conditioned place preference to COC (LaPlant et al., 2010; Tian et al., 2012), indicating that DNA methylation may play a role in 
COC reward processing. However, the aforementioned studies did not address the shared mechanism underlying both sensitization, a defining characteristic of addiction in which repeated drug exposure induces neuroadaptations to behavioral and synaptic plasticity, and relapse (Robinson and Berridge, 1993; Vezina, 2004; Steketee and Kalivas, 2011). Thus, one of the aims of this study was to investigate the role of DNA methylation in locomotor sensitization to COC and reinstatement to COC and associated cues.

We hypothesized that chronic MET treatment would reduce addictive-like behaviors via DNA methylation-dependent processes. First, we investigated the effect of MET on locomotor sensitization, in which repeated exposure to COC results in subsequent increases in locomotor activity. Next, we assessed the effects of MET on intravenous COC self-administration and subsequent drug-seeking behaviors during cue-induced and COCprimed reinstatement. We also assessed the effects of MET on sucrose pellet reinstatement to determine whether its effects extend to natural reward. We then measured expression of Dnmt1, Dnmt3a, Dnmt3b, and global DNA methylation in two areas of the neural circuitry responsible for drug-seeking behavior, the nucleus accumbens core (NAc) and the medial prefrontal cortex (mPFC; McFarland and Kalivas, 2001; Kalivas and Volkow, 2005), both of which are shown to be hypoactive at rest and overactive in response to COC in rats and humans (Goldstein and Volkow, 2002; Sun and Rebec, 2006). Finally, given the rapid induction by COC of c-Fos, an immediate early gene product and marker of neuronal activation (Graybiel et al., 1990; Neisewander et al., 2000), we examined whether MET affects the reward circuitry as indicated by blocking COC-induced c-Fos expression.

\section{Materials and Methods}

Animals

All experiments were performed according to the National Institutes of Health Guide for Care and Use of Laboratory Animals (National Research Council, 1996) and were approved by the Florida State University Institutional Animal Care and Use Committee of Florida State University. Male Sprague Dawley rats weighing 225-250 g (Charles River) were initially pair housed in $43 \times 21.5 \times 25.5 \mathrm{~cm}$ Plexiglas cages on a $12 \mathrm{~h}$ light/dark cycle. Locomotor activity was assessed during the first $4 \mathrm{~h}$ of their light cycle. Operant training was conducted at least $2 \mathrm{~h}$ after the onset of the dark cycle. Food and water were provided ad libitum. After catheter implantation, animals were single housed for the duration of the experiment.

For jugular catheter surgery, heparin-coated catheters (Instech Laboratories) were attached with epoxy to back-mounted cannulae with a 10 $\mathrm{mm}$ upward projection (Plastics One). Surgery was conducted under sterile conditions. Rats were anesthetized with an intramuscular injection of ketamine $(70 \mathrm{mg} / \mathrm{kg}$ ) and xylazine $(10 \mathrm{mg} / \mathrm{kg})$, a $1 \mathrm{~cm}$ incision was made, and the right external jugular vein was dissected bluntly. After creating a subcutaneous passage for the catheter to pass from the midscapular region to the front, the jugular vein was incised halfway with artery scissors, and the catheter tubing was installed and tied into place using silk suture. Finally, incision sites were sutured, and rats were treated with a topical analgesic $(0.25 \mathrm{mg} / \mathrm{kg}$ bupivacaine $)$ and an antiinflammatory $(5 \mathrm{mg} / \mathrm{kg}$ carprofen, i.p.). Catheters were flushed twice daily with $0.1 \mathrm{ml}$ of heparinized saline (SAL; $50 \mathrm{U} / \mathrm{ml}$ heparin) and ampicillin $(30 \mathrm{mg} / \mathrm{ml})$. After $2-3 \mathrm{~d}$ of recovery, the self-administration procedure began. Catheter patency was tested with $20 \mathrm{mg} / \mathrm{kg}$ ketamine $4 \mathrm{~d}$ after surgery and after $10 \mathrm{~d}$ of acquisition. These heparin-coated catheters have been shown previously to maintain patency for at least $30 \mathrm{~d}$ with twice weekly heparin flushes (Foley et al., 2002). One rat was removed from the study because of a failed catheter.

Drugs

Cocaine hydrochloride (generously donated by National Institute on Drug Abuse) was dissolved in $0.9 \%$ sterile SAL at a dose of $0.75 \mathrm{mg} / \mathrm{kg}$ per infusion for the COC self-administration experiment and $10 \mathrm{mg} / \mathrm{kg}$ intraperitoneally for the sensitization experiment and for drug-induced reinstatement. MET $(10.4 \mathrm{mmol} / \mathrm{ml}$, dissolved in SAL and injected at 1 $\mathrm{ml} / \mathrm{kg}$, s.c.) or SAL was injected once daily, $1-2 \mathrm{~h}$ before behavioral testing, starting on the first day of behavioral sensitization or selfadministration and lasting the duration of the experiment. This dose of MET, used previously by our group, is within a range that has been shown to increase SAM levels in the brain (Tremolizzo et al., 2002; LaPlant et al., 2010).

\section{Behavioral testing}

Novelty response. Because individual differences in novelty-seeking behaviors influences response to drugs of abuse (Kabbaj, 2006), classification as high responders (HRs) or low responders (LRs) was determined to balance HR and LR rats equally between experimental groups, based on the group median split of their exploratory behavior described previously (Dietz et al., 2008). Briefly, at the beginning of the light cycle, all rats underwent a $1 \mathrm{~h}$ locomotor test in a novel donut-shaped arena $71.2 \mathrm{~cm}$ in diameter with four equidistant photobeam sensors (Med Associates), and locomotor activity was quantified by the number of beam breaks. This classification was only used for assigning experimental groups, and no other statistical analyses are reported.

Drug-induced locomotor sensitization. A separate cohort of rats was used for this experiment. On day 1 , rats were given $1 \mathrm{~h}$ to habituate to a donut-shaped arena, injected with SAL ( $1 \mathrm{ml} / \mathrm{kg})$, and given 1 additional hour to habituate to the stress of injection. The rats were then removed briefly from the arena and given an injection of COC $(10 \mathrm{mg} / \mathrm{kg}$, i.p.), followed by $2 \mathrm{~h}$ in which they were allowed to move freely within the arena. All $4 \mathrm{~h}$ of locomotor activity were measured, and the number of photobeam breaks in $10 \mathrm{~min}$ time bins were recorded. Then, the rats were given an injection of COC in their home cage on days 4 and 7, before repeating the same locomotor procedure on day 10 as was done on day 1 .

Operant training. Animals were trained to respond for $45 \mathrm{mg}$ sucrose pellets under an fixed ratio 1 (FR1) schedule of reinforcement for $1 \mathrm{~h}$ each day in standard operant chambers $(30.5 \times 24.1 \times 21.0 \mathrm{~cm}$; Med Associates) in sound-attenuating cabinets. The chambers were equipped with two nose-poke holes: an active response resulted in a sucrose pellet reward, with the house light turning off for a $7.2 \mathrm{~s}$ timeout duration during which time no responses were reinforced, and a cue light turning on for 10 s. An inactive response had no programmed consequences. Rats trained daily until they met the criteria of a minimum of three trials with at least 15 active responses with $<20 \%$ variability between them and active responses at least $75 \%$ higher than inactive responses. Number of sucrose pellets, active responses, and inactive responses were recorded.

Sucrose pellet training, measurement of body weights, and food and water intake. A separate cohort of rats was used for this experiment. Animals were housed two per cage and trained to self-administer sucrose pellets as described above. Once rats reached criteria for advancement, they continued self-administering sucrose pellets for $10 \mathrm{~d}$ under the same conditions, and they were treated daily with MET or SAL. Additionally, their food and water intake and their body weights were measured daily.

COC self-administration procedure, extinction, and reinstatement trials. Rats self-administered $0.75 \mathrm{mg} / \mathrm{kg}$ per infusion intravenous COC or SAL in the same operant chamber in which they initially trained using sucrose pellets, for a $2 \mathrm{~h}$ trial with an FR1 schedule of reinforcement with 100 maximum infusions possible. During the trial, an active response resulted in the following: a cue light turned on for $10 \mathrm{~s}$, a COC infusion was delivered intravenously over the course of $2.8 \mathrm{~s}$, and house lights turned off for a 7.2-s timeout period, during which time active and inactive responses were counted but no infusions were available until the house light turned back on. Selection of the inactive nose-poke hole had no programmed function. Animals trained once daily until criteria for advancement was achieved (a minimum of 10 trials, with 25 or more infusions on the last $3 \mathrm{~d}$ ). Infusions, active responses, and inactive responses were recorded. At the end of each trial, catheters were flushed with heparinized SAL, and rats were returned to their home cages. After reaching the minimum criteria for acquisition, animals underwent daily $2 \mathrm{~h}$ extinction trials in which the house light was off, COC was unavailable, and there were no programmed responses for either active or inactive selec- 
Table 1. Primer sequences used for RT-qPCR and bisulfite sequencing

\begin{tabular}{llll}
\hline Primer & Forward & Reverse & Reference \\
\hline NADH & CTATTAATCCCCGCCTGACC & GGAGCTCGATTTGTTTCTGC & Duclot and Kabbaj, 2013 \\
Dnmt1 & CAGATGTTCCATGCACACT & TGTGGATGTAGGAAAGTTGCA & Zhou et al., 2013 \\
Dnmt3a & ACGCCAAAGAAGTGTTGCT & CTTGCCCTGCTTTATGGAG & LaPlant et al., 2010 \\
Dnmt3b & CGTGATTCTGGGGGAGGTTC & Own design \\
Hprt1 & TCACCCGAGAGACCAAGGAT & GTCTGGCCTGTATCCAACACT & Sarkar et al., 2014 \\
c-Fos & GCAGACTTTGCTTTCCTTGG & ACATCTCCGGAGAGGTGAG & Echeverry-Alzate et al., 2012 \\
c-Fos_Bis & ACCTCAAGGACTTGAAAGCATC & ACTCTATCCAATCTTCTCAATTACTAA & Dyrvig et al., 2012 \\
\hline
\end{tabular}

Bis, Bisulfite.

tions. Active and inactive responses were recorded. When the rats reached criteria for advancement ( 10 trials, a $75 \%$ reduction from their final acquisition trial, and $<20 \%$ variability in active responses compared across the last three trials), they underwent a single cue-induced reinstatement trial, in which contextual cues that previously indicated COC availability were present but COC was not available. Active and inactive responses were recorded. Two days of extinction trials identical to previous extinction trials followed, because this was sufficient to return all rats to levels of responding comparable with extinction before cue reinstatement. Next they underwent a COC-primed reinstatement trial, in which rats were injected with COC $(10 \mathrm{mg} / \mathrm{kg}$, i.p. $)$ and placed immediately in the operant chamber for one $2 \mathrm{~h}$ trial with no cues or programmed responses. Animals were killed by rapid decapitation immediately after the end of the trial. Brains were dissected, flash frozen in cold 2-methylbutane, and stored at $-80^{\circ} \mathrm{C}$ for future use.

Sucrose self-administration procedure, extinction, and reinstatement trials. A separate cohort of rats underwent an experiment identical to the one described above to see whether the effects of MET generalize to natural reinforcers. After determining HR/LR status and initial sucrose pellet training as described above, rats underwent $10 \mathrm{~d}$ of acquisition identical to the COC self-administration experiment, except active responses were reinforced with $45 \mathrm{mg}$ sucrose pellets instead of intravenous COC (FR1 schedule of reinforcement, $2 \mathrm{~h}$ trial, 100 pellets maximum). Extinction trials and reinstatement trials were also the same as the previous cohort. Finally, rats underwent a pellet-primed reinstatement trial, in which five sucrose pellets were delivered noncontingently at the beginning of the trial, which was otherwise identical to the extinction trials. Active and inactive responses were recorded.

Tissue processing

Brains from the COC reinstatement experiment were sectioned at 200 $\mu \mathrm{m}$, and the mPFC and NAc were punched bilaterally according to Paxinos and Watson (2006). DNA and RNA were extracted using TriReagent (Molecular Research Center) according to the instructions of the manufacturer.

\section{Real-time RT-qPCR}

RT-qPCR was performed as described previously (Hollis et al., 2011), with some modifications. Briefly, RNA was reverse transcribed using Cloned AMV First-Strand cDNA Synthesis kit (Invitrogen). cDNA was analyzed in triplicates in a 384-well plate using a CFX thermal cycler (Bio-Rad), with SYBR Green as the fluorescent detector for the qPCR reaction. Nicotinamide adenine dinucleotide dehydrogenase (NADH) was used as a reference gene except when noted in Results. Results are depicted as percentage change from controls (SAL/SAL). For primer sequences, see Table 1.

\section{Global DNA methylation}

Genomic DNA samples were purified using QIAquick PCR Purification kit (Qiagen) and hydrolyzed using DNA Degradase Plus (Zymo Research) according to the instructions of the manufacturer. DNA electrophoresis was performed on a $1 \%$ agarose gel to confirm thorough digestion of samples (data not shown). C18 reverse-phase liquid chromatography separation followed by electrospray ionization tandem mass spectrometry (LC-ESI MS/MS) was used to detect levels of 5-methyl-2' deoxycytidine $(5 \mathrm{mdC})$ in the NAc and $\mathrm{mPFC}$ as described previously (Song et al., 2005). LC was performed using a Waters Symmetry C18 5 $\mu \mathrm{m} 0.180 \times 20 \mathrm{~mm}$ trap column and a Waters HSS T3 $1.8 \mu \mathrm{m} 0.075 \times$ $150 \mathrm{~mm}$ analytical column. The LC buffers were $0.1 \%$ formic acid in water (buffer A) and $0.1 \%$ formic acid in acetonitrile (buffer B). Two microliter injections were loaded on the trap column for $1 \mathrm{~min}$ at 15 $\mu \mathrm{l} / \mathrm{min} 1 \%$ buffer B. Elution from the analytical column was at 400 $\mathrm{nl} / \mathrm{min}$ using a gradient of $1 \%$ buffer $\mathrm{B}$ at run start, $50 \%$ buffer $\mathrm{B}$ at $5 \mathrm{~min}$, $85 \%$ buffer B from $7-10 \mathrm{~min}$, and $1 \%$ buffer B at $11 \mathrm{~min}$. Samples were run in duplicate on a Xevo TQ-S Triple Quadupole mass spectrometer (Waters) using multiple reaction monitoring transitions of 228.2/112.2 [deoxycytidine (dC)], 242.1/126/3 (5mdC). 243.3/127.2 [thymidine (T)], 252.3/135.9 [2'-deoxyadenosine (dA)], and 268.1/152.3 [2'deoxyguanosine (dG)], all at $3 \mathrm{~ms}$ dwell time, $20 \mathrm{~V}$ cone voltage, 0.20 bar spray gas, and $8 \mathrm{eV}$ collision energy. Chromatograms were acquired and compared with a standard curve of calibration solutions containing 40 $\mathrm{pmol} / \mu \mathrm{l}$ each of $5 \mathrm{mdC}+\mathrm{dC}, \mathrm{dG}, \mathrm{dA}$, and $\mathrm{T}(160 \mathrm{pmol} / \mu \mathrm{l}$ total $)$ with $5 \mathrm{mdC}$ concentrations of $0.05,0.1,0.25,0.5,1.0,2.5,5.0$, and $10 \%(r=$ $0.9984)$. Data are presented as percentage of $5 \mathrm{mdC}$ to total $\mathrm{dC}$.

\section{Bisulfite sequencing}

Genomic DNA was bisulfite treated using EpiTect Bisulfite kit (Qiagen), and a portion of the c-Fos promoter from -163 to 16 bp was amplified using JumpStart REDTaq DNA Polymerase (Sigma), resulting in a PCR product of 236 bp containing $12 \mathrm{CpG}$ dinucleotides (Dyrvig et al., 2012). Thirty nanograms of bisulfite-converted DNA were amplified as follows: $95^{\circ} \mathrm{C}$ for $5 \mathrm{~min}$; 35 cycles of $95^{\circ} \mathrm{C}$ for $1 \mathrm{~min}, 55^{\circ} \mathrm{C}$ for $2.5 \mathrm{~min}, 72^{\circ} \mathrm{C}$ for 1 $\mathrm{min}$; and $72^{\circ} \mathrm{C}$ for $5 \mathrm{~min}$. The samples were run on a $1 \%$ agarose gel to confirm primer specificity. PCR products were then extracted and purified using GenElute Gel Extraction kit (Sigma) and sent to the sequencing facility of Florida State University, where samples were sequenced by capillary electrophoresis against the reverse primer. DNA standards of known methylation were processed alongside experimental samples, and a standard curve was derived to confirm accuracy of sequencing (EpigenDx). Chromatograms were analyzed, and the peak ratio was calculated as follows: $C /(C+T) \times 100$, to determine the percentage of DNA methylation at each of the $12 \mathrm{CpG}$ dinucleotides and the average methylation across all CpGs.

\section{Statistical analysis}

For locomotor sensitization, two-way repeated-measures ANOVA was used with phase of experiment (habituation, SAL, or COC) or $10 \mathrm{~min}$ time bins as the within-groups factor and treatment (SAL or MET) as the between-groups factor. One-way repeated-measures ANOVA was used to compare treatment over time during the COC portion of the experiment. For the self-administration data, repeated-measures two-way ANOVA was used with trial as the within-subjects factor, and treatment (SAL or MET) and self-administration (SAL or COC) as the betweensubjects factors. For reinstatement trials, paired two-tailed $t$ tests were used to compare the respective extinction response of each group to reinstatement. Two-way ANOVA was used to analyze RT-qPCR, global methylation, and c-Fos methylation results with treatment and selfadministration as the independent variables. Regression analysis was used to compare active responses during COC-primed reinstatement and c-Fos mRNA levels. GraphPad Prism 4.3 (GraphPad Software) and StatView 5.0.1 (SAS Institute) were used for data analyses. Data are depicted as mean \pm SEM, and the level of significance was set to 0.05 . Post hoc comparisons were made with Bonferroni's corrections when appropriate. 

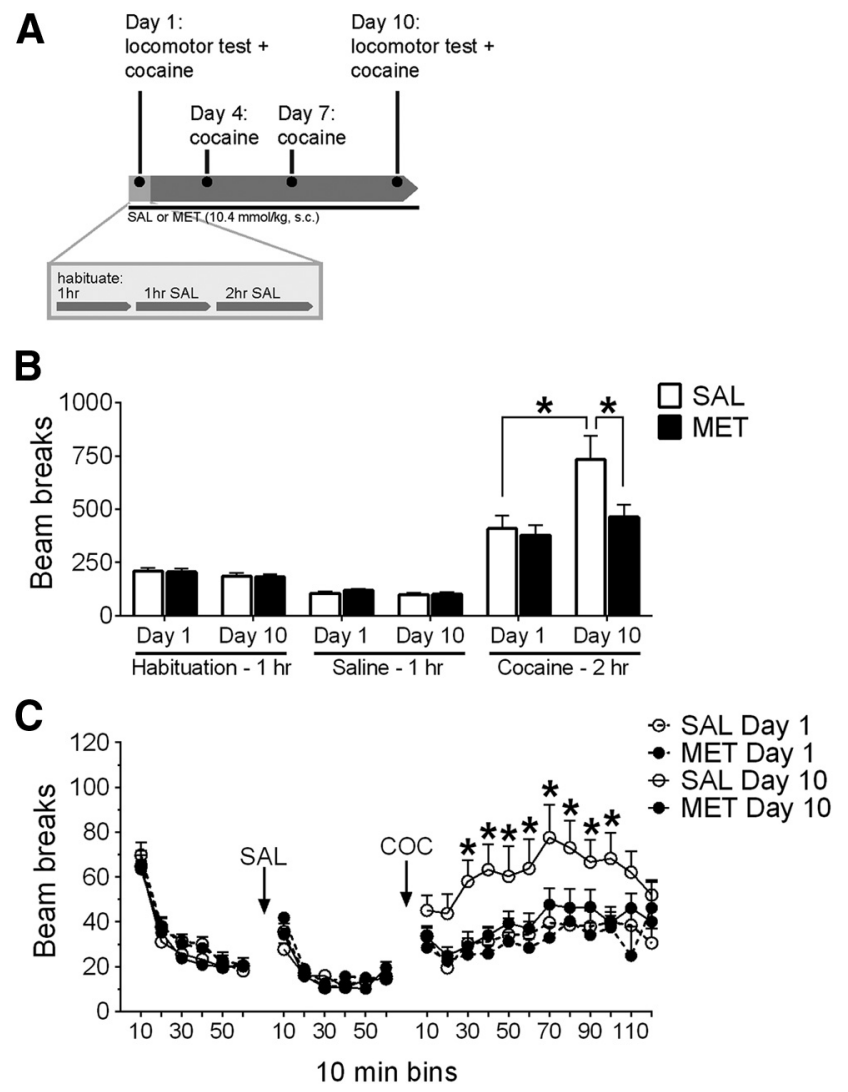

Figure 1. MET treatment blocks $C O C$-induced locomotor sensitization. $A$, The experimental timeline. $\boldsymbol{B}$, Locomotor activity in each phase of the experiment, measured by beam breaks. No differences were observed between SAL- and MET-treated rats on day 1 versus day 10 for the $1 \mathrm{~h}$ habituation or $1 \mathrm{~h}$ with SAL injection. On day 1 during the $2 \mathrm{~h}$ of $\mathrm{COC}$, no differences were observed between SAL and MET. On day 10, SAL-treated rats exhibited a significantly higher locomotor response compared with their day 1, whereas MET-treated rats exhibited no differences between day 1 and day 10. C, Locomotor activity in 10 min bins. SAL-treated rats had a significantly higher response on day 10 compared with day 1. Data are presented as mean \pm SEM. ${ }^{*} p<0.05$, Bonferroni's post hoc test, $n=18-20$ per group.

\section{Results}

\section{COC-induced locomotor sensitization}

To determine the effects of methyl supplementation on the psychomotor-activating effects of COC, we administered 10.4 $\mathrm{mmol} / \mathrm{kg}$ MET or SAL daily and $10 \mathrm{mg} / \mathrm{kg}$ COC every third day for $10 \mathrm{~d}$ (for the timeline, see Fig. $1 A$ ). We then examined total locomotor scores on the first and last days of treatment (Fig. 1B). One-way repeated-measures ANOVA indicated a significant increase in locomotor response to COC from day 1 to day 10 for SAL-treated rats $\left(F_{(1,19)}=7.756, p=0.012\right)$ but not MET-treated rats $\left(F_{(1,17)}=3.099, p=0.096\right)$, indicating that SAL-treated rats sensitized to COC but MET-treated rats did not. On day 1, twoway repeated-measures ANOVA indicated no significant effect of treatment on locomotor activity across the three phases of the experiment: habituation, SAL, and $\operatorname{COC}\left(F_{(1,36)}=0.044, p=\right.$ $0.8360, n=18-20$ per group). Day 10 two-way repeatedmeasures ANOVA indicated a significant interaction of treatment and phase of trial $\left(F_{(2,36)}=4.678, p=0.012, n=18-20\right.$ per group). Bonferroni's post hoc analysis showed that SAL-treated rats exhibited a significant increase in locomotor response compared with MET on day 10 during the $2 \mathrm{~h} \mathrm{COC}$ measurement $\left(t_{(36)}=4.242, p<0.001\right)$, indicating a heightened response to COC from SAL-treated, but not MET-treated, animals. Figure $1 C$ shows 10 min time bins for each phase of the

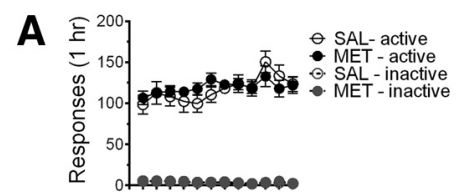

B
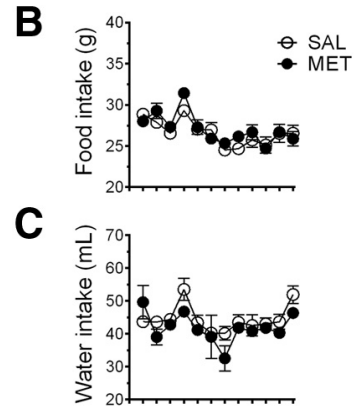

D

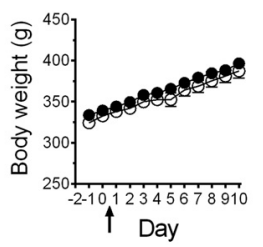

Figure 2. MET treatment had no effect on sucrose pellet self-administration and consummatory behaviors. $\boldsymbol{A}$, Active and inactive responses to sucrose pellets. Food intake $(\boldsymbol{B})$, water intake $(\boldsymbol{C})$, and body weights $(\boldsymbol{D})$ were measured daily during $10 \mathrm{~d}$ of MET or SAL treatment and sucrose self-administration, and no differences were found. Data are presented as mean \pm SEM. $n=10$ per group. Arrow indicates onset of MET treatment.

experiment. Two-way repeated-measures ANOVA indicated a significant interaction of time $\times$ treatment $\left(F_{(3,69)}=3.198, p<\right.$ 0.0001 ). Bonferroni's post hoc analysis shows day $10 \mathrm{SAL}$ as statistically significant from day $1 \mathrm{SAL}$, day $1 \mathrm{MET}$, and day $10 \mathrm{MET}$ $(p<0.05)$.

\section{Sucrose pellet acquisition, body weights, and food and water} intake with MET treatment

To determine whether the effects of MET extend to sucrose pellet acquisition and whether there are potential side effects of MET, a separate cohort of rats were treated with MET for $10 \mathrm{~d}$, and body weights along with food and water intake were measured daily during sucrose self-administration. There was a significant main effect of time $\left(F_{(1,198)}=4.245, p<0.001\right)$ but no effect of treatment on active responses $\left(F_{(1,18)}=0.081, p=0.7796\right.$, one-way repeated-measures ANOVA; Fig. 2A). Daily food intake is shown in Figure $2 B$. There was a significant main effect of day $\left(F_{(11,198)}=\right.$ 19.07, $p<0.0001)$ but no effect of MET treatment $\left(F_{(1,18)}=\right.$ $0.414, p=0.528)$. Daily water consumption showed a main effect for day $\left(F_{(11,198)}=5.847, p<0.0001\right)$ but no effect of treatment $\left(F_{(1,18)}=1.729, p=0.205\right.$; Fig. $\left.2 C\right)$. Finally, there was a significant main effect of day $\left(F_{(11,198)}=197.1, p<0.0001\right)$ but no effect of MET treatment $\left(F_{(1,18)}=1.418, p=0.249, n=10\right.$ per group) on body weights $1-2 \mathrm{~d}$ before and during $10 \mathrm{~d}$ of MET treatment (Fig. 2D).

\section{The effects of MET on COC self-administration, extinction,} and reinstatement

Given the ability of MET to attenuate the psychomotoractivating and place conditioning effects of COC (LaPlant et al., 2010), we hypothesized that MET treatment might also block the reinforcing properties of the drug. Thus, after completion of sucrose pellet training, we treated rats with either MET or SAL and 
allowed them to self-administer COC $(0.75 \mathrm{mg} / \mathrm{kg}$ per infusion $)$ or SAL, followed by $10 \mathrm{~d}$ of extinction (timeline shown in Fig. 3A). There were no differences observed in sucrose pellet training before MET treatment (data not shown). During acquisition, COC selfadministering rats had significantly higher rates of infusions than SAL selfadministrating rats (two-way repeatedmeasures ANOVA, $F_{(3,64)}=5.039, p=$ 0.0034; Fig. 3B). A significant main effect of self-administration on active responses during acquisition was observed $\left(F_{(1,64)}=\right.$ $9.718, p=0.0027)$, but no effect of MET was observed $\left(F_{(1,64)}=0.148, p=0.702\right.$, $n=11-23$ per group; Fig. $3 C$ ). Similarly, during extinction, we observed a significant main effect of active responses $\left(F_{(1,45)}=\right.$ $11.761, p=0.0013)$ but no MET effect $\left(F_{(1,45)}=0.050, p=0.8170\right)$. Notably, the number of inactive responses remain unchanged throughout the procedure $\left(F_{(1,61)}=0.8132, p=0.7366\right)$. Therefore, MET treatment did not affect acquisition or extinction of $\mathrm{COC}$ self-administration.

After $10 \mathrm{~d}$ of extinction, cues were returned to the operant chambers for a single trial of cue-induced reinstatement (Fig. 3D). Although the number of active responses was significantly higher during the cue-induced reinstatement compared with the last day of extinction $\left(F_{(1,45)}=\right.$ $27.72, p<0.0001$, main effect of trial), no effect of treatment was observed $\left(F_{(1,45)}=\right.$ $1.014, p=0.395, n=11-13$ per group), suggesting that MET did not affect cueinduced reinstatement. Additionally, all groups exhibited increased active responses during cue-induced reinstatement compared with their final extinction trial (SAL/MET, $t_{(20)}=2.958, p=0.0078$; COC/SAL, $t_{(24)}=2.897, p=0.0079$; and COC/MET, $\left.t_{(26)}=2.620, p=0.0145\right)$, with a trend toward significance for SAL/ $\operatorname{SAL}\left(t_{(20)}=2.034, p=0.0554\right.$, two-tailed paired $t$ tests), demonstrating that cue-induced reinstatement was observed regardless of MET treatment. After $2 \mathrm{~d}$ of extinction training to return their responses to baseline levels, rats were injected with COC $(10 \mathrm{mg} / \mathrm{kg}$, i.p. $)$ immediately before the trial to assess drug-seeking behavior under COC-primed reinstatement (Fig. 3E). Two-way repeated-measures ANOVA revealed a significant main effect for trial $\left(F_{(1,42)}=18.58, p<\right.$ $0.0001)$, treatment $\left(F_{(1,42)}=2.96, p=0.041\right)$, and an interaction $\left(F_{(3,42)}=2.908, p=0.045, n=11-13\right.$ per group $)$. Bonferroni's post hoc comparisons were performed to analyze pairwise comparisons by trial. There was a significant difference between SAL/ SAL versus COC/SAL $(t=3.483, p<0.05)$, SAL/MET versus COC/SAL $(t=3.735, p<0.001)$, and COC/SAL versus COC/ MET $(t=2.759, p<0.05)$. Notably, although rats that selfadministered SAL did not exhibit more active responses during COC-primed reinstatement compared with their final extinction
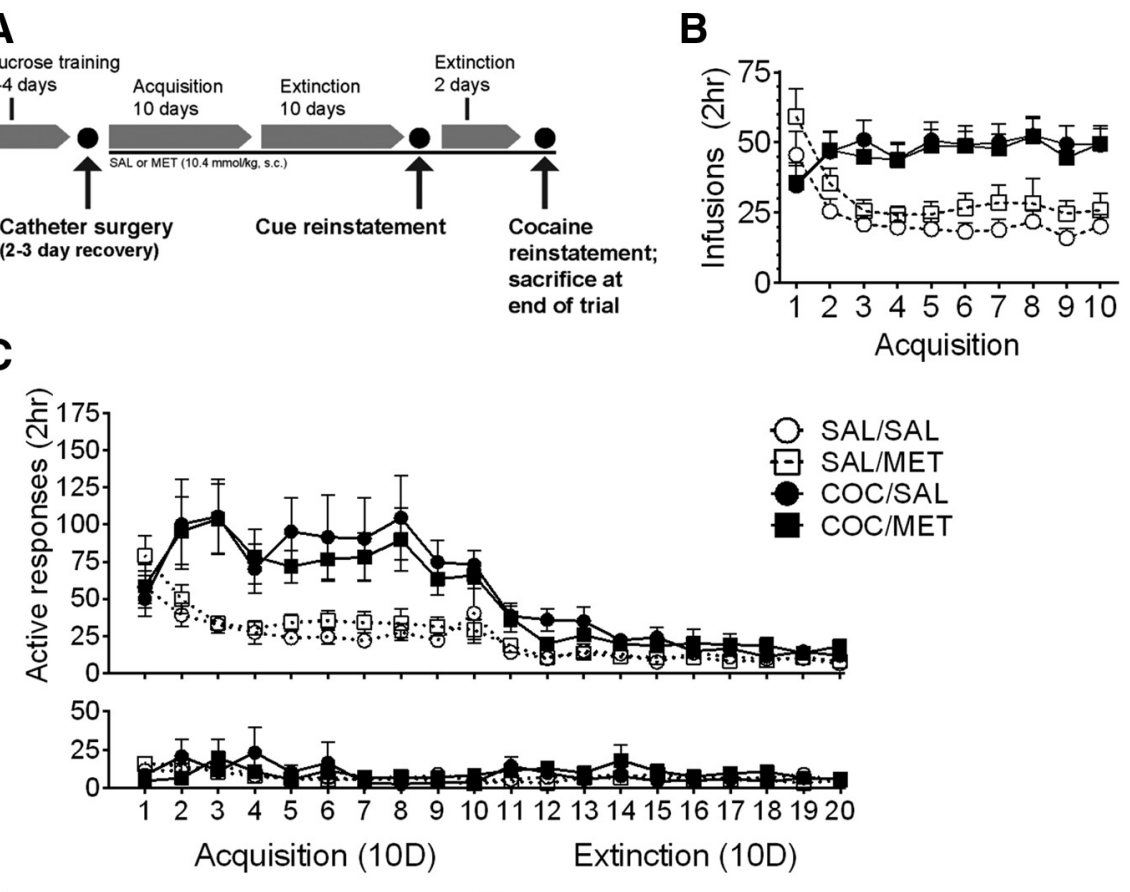

E
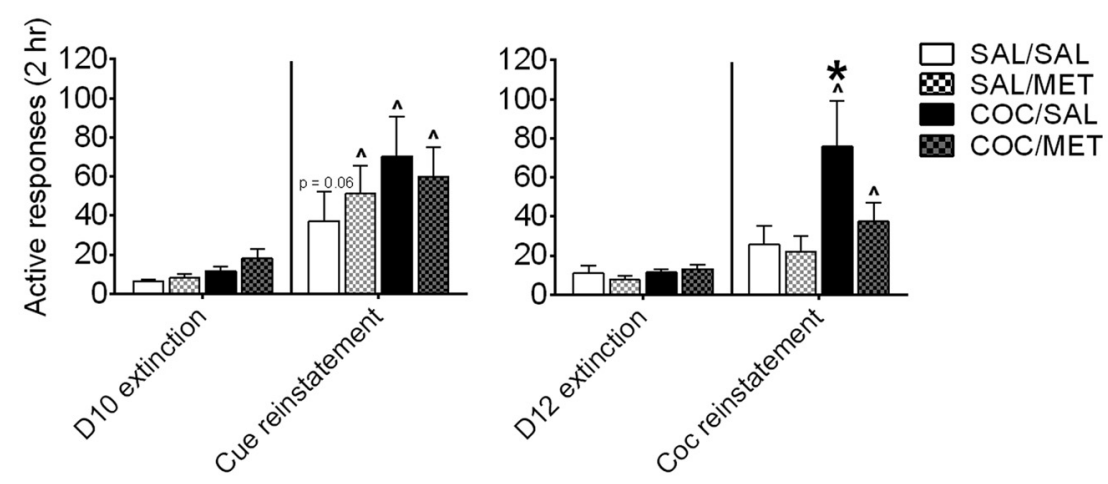

Figure 3. MET treatment effects on COC self-administration, extinction, and reinstatement. $\boldsymbol{A}$, Timeline of experimental design. $\boldsymbol{B}$, Number of infusions during $10 \mathrm{~d}$ of acquisition of $\mathrm{COC}$ or SAL self-administration. No effect of MET treatment was observed. $\boldsymbol{C}$ of active and inactive responses during $10 \mathrm{~d}$ of acquisition and $10 \mathrm{~d}$ of extinction. No effect of MET treatment was observed. responses during the final extinction trial and the subsequent cue reinstatement trial. MET treatment had no effect on rextinction trial and the subsequent COC reinstatement trial. Whereas rats that self-administered COC reinstated to a COC prime, SAL-treated rats exhibited a significantly higher active response that was not observed in MET-treated rats. Data are presented as mean \pm SEM. ${ }^{\wedge} p<0.05$ compared with extinction, ${ }^{*} p<0.05$ compared with SAL/SAL, Bonferroni's post hoc test. $n=11-23$ per group for $\boldsymbol{B}$ and $\boldsymbol{C} ; n=11-13$ per group for $\boldsymbol{D}$ and $\boldsymbol{E}$.

trial $\left(t_{(20)}=1.425, p=0.1697\right.$ for SAL/SAL; $t_{(20)}=1.689, p=$ 0.1068 for SAL/MET), there was a significant increase for rats that self-administered $\operatorname{COC}\left(t_{(20)}=2.722, p=0.0131\right.$ for COC/SAL; $t_{(24)}=2.510, p=0.0192$ for COC/MET). Together, rats that had self-administered COC reinstated to a priming injection compared with their responses during extinction; however, the degree of response was significantly lower in MET-treated animals, indicating that MET treatment attenuated COCprimed reinstatement.

The effects of MET on sucrose self-administration, extinction, and reinstatement

To assess the effects of MET on sucrose pellet reinstatement, rats underwent a similar procedure as in the COC self-administration experiment (for the timeline, see Fig. 4A). There were no initial differences observed in sucrose pellet training before MET or SAL 
A

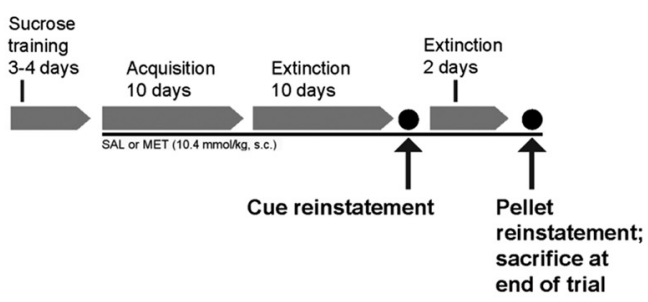

C

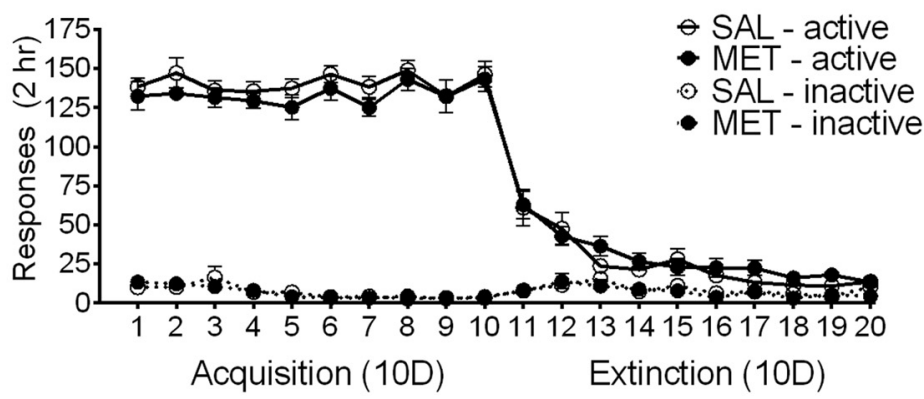

D

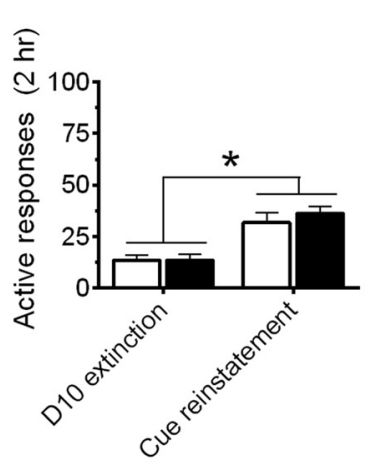

E

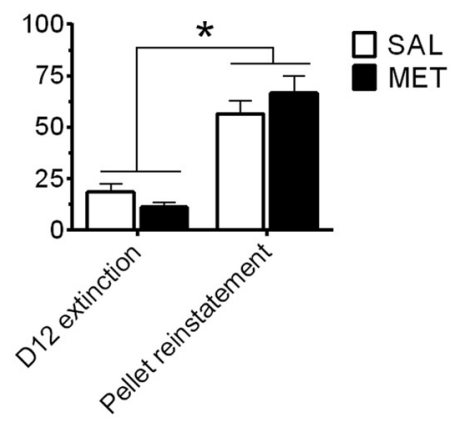

Figure 4. MET treatment has no effect on reinstatement to sucrose pellets after sucrose self-administration. $\boldsymbol{A}$, Timeline of experimental design. $\boldsymbol{B}$, Number of pellets taken during acquisition. $\boldsymbol{C}$, Active and inactive responses during $10 \mathrm{~d}$ acquisition and $10 \mathrm{~d}$ extinction. No differences were observed between SAL- and MET-treated rats. $\boldsymbol{D}$, Active responses during cue-induced reinstatement show that both groups reinstated to cues equally compared with their respective active responses on day 10 extinction. $\boldsymbol{E}$, Active responses during pellet-primed reinstatement show that both groups exhibited pellet-seeking behavior compared with their responses on day 12 extinction. Data were analyzed by two-way repeated-measures ANOVA and presented as mean \pm SEM. $n=10$ per group. ${ }^{*} p<0.05$ compared with extinction trial.

treatment (data not shown). During acquisition for the number of pellets self-administered, there was a main effect of trial (two-way repeated-measures ANOVA, $F_{(1,9)}=1.961, p=0.0471$ ), but no effect of MET treatment was observed $\left(F_{(1,18)}=3.201, p=0.0904\right.$; Fig. $4 B)$. Similarly, for active responses during acquisition, there was a main effect of trial $\left(F_{(1,9)}=2.252, p=0.0213\right)$, but no effect of treatment $\left(F_{(1,18)}=1.218, p=0.2843\right.$; Fig. $\left.4 C\right)$. Inactive responses during acquisition revealed a main effect of trial $\left(F_{(1,9)}=7.199, p<\right.$ $0.0001)$ but no effect of treatment $\left(F_{(1,18)}=0.02782, p=0.869\right)$. For active responses during extinction, there was a main effect of trial $\left(F_{(1,9)}=19.25, p<0.0001\right)$ but no effect of treatment $\left(F_{(1,18)}=\right.$ $3.872, p=0.4350)$. Inactive responses during extinction revealed a main effect of trial $\left(F_{(1,9)}=2.080, p=0.0341\right)$ but no effect of treatment $\left(F_{(1,18)}=0.8445, p=0.3703\right)$. Together, MET treatment had no effect on sucrose pellet acquisition and extinction.

When comparing active responses on the last extinction trial with cue-induced reinstatement (Fig. $4 D$ ), there was a significant main effect of trial $\left(F_{(1,18)}=37.82, p<0.0001\right)$ but no main effect of MET treatment $\left(F_{(1,18)}=0.3230, p=0.5789\right.$, two-way repeated-measures ANOVA). There was a significant increase in active responses during cue-induced reinstatement compared with the last day of extinction for both SAL-treated rats $\left(t_{(9)}\right.$ $=3.166, p=0.0114)$ and MET-treated rats $\left(t_{(9)}=6.708, p<0.0001, n=10\right.$ per group), indicating that both groups reinstated to cues. Unpaired $t$ tests comparing SAL and MET cue-induced reinstatement shows no differences $\left(t_{(18)}=0.7414, p=\right.$ 0.4680 ). For pellet-primed reinstatement (Fig. $4 E$ ), there was a significant main effect of trial $\left(F_{(1,18)}=64.54, p<0.0001\right)$ but no main effect of treatment $\left(F_{(1,18)}=\right.$ $0.05057, p=0.8246$, two-way repeatedmeasures ANOVA). There was a significant increase in active responses during pellet-primed reinstatement compared with day 12 extinction for both SALtreated rats $\left(t_{(9)}=5.247, p=0.0005\right)$ and MET-treated rats $\left(t_{(9)}=6.092, p=\right.$ $0.0002, n=10$ per group), indicating that both groups reinstated to a pellet priming. Unpaired $t$ tests comparing SAL and MET pellet-primed reinstatement responses revealed no differences $\left(t_{(18)}=0.9810, p=\right.$ 0.3396). Together, MET treatment had no effect on operant behaviors to obtain a natural reward, and thus its effects do not generalize to sucrose reward.

\section{The effects of COC self-administration and MET on Dnmt expression}

After the COC-primed reinstatement trial, rats were killed, and mRNA was extracted from the NAc and mPFC to measure mRNA levels of Dnmt1, Dnmt3a, and $D n m t 3 b$ by RT-qPCR (Fig. $5 A, B$ ). In the NAc, whereas Dnmt1 expression remained unaffected $\left(F_{(1,20)}=0.0456, p=\right.$ 0.8330 for self-administration effect; $F_{(1,20)}=0.4104, p=0.5290$ for MET effect), Dnmt3a and Dnmt3b were upregulated in COC self-administering rats, regardless of SAL or MET treatment $\left(F_{(1,20)}=9.265, p=0.006\right.$ and $F_{(1,17)}=10.89, p=0.004$ for self-administration effect, respectively; $F_{(1,20)}=0.1043, p=0.750$ and $F_{(1,17)}=0.1674, p=$ 0.688 for main effect of MET, respectively). In the $\mathrm{mPFC}$, Dnmt 1 $\left(F_{(1,20)}=1.310, p=0.2658\right.$ for self-administration main effect; $F_{(1,20)}=0.9352, p=0.3451$ for MET effect $), \operatorname{Dnmt} 3 a\left(F_{(1,20)}=\right.$ $0.1488, p=0.7038$ for self-administration main effect; $F_{(1,20)}=$ $1.094, p=0.3081$ for MET effect), and $\operatorname{Dnmt3b}\left(F_{(1,20)}=0.00243\right.$, $p=0.9612$ for self-administration main effect; $F_{(1,20)}=0.1012, p=$ 0.7537 for MET main effect, $n=5-6$ per group) expression were unaffected. To account for possible regulation of NADH by COC exposure (del Castillo et al., 2009), we compared NADH against a different reference gene, hypoxanthine guanine phosphoribosyl transferase 1 (Hprt1). No differences were observed $\left(F_{(1,18)}=\right.$ 1.451, $p=0.2440$, self-administration main effect; $F_{(1,18)}=$ $0.0022, p=0.9633$, MET effect, $n=5-6$ per group), supporting that NADH is not regulated by the treatment. To further confirm our results, we normalized Dnmt3a against Hprt1 and confirmed the upregulation of Dnmt3a mRNA in the NAc by COC selfadministration $\left(F_{(1,18)}=7.803, p=0.0120\right.$, main effect of self- 
A

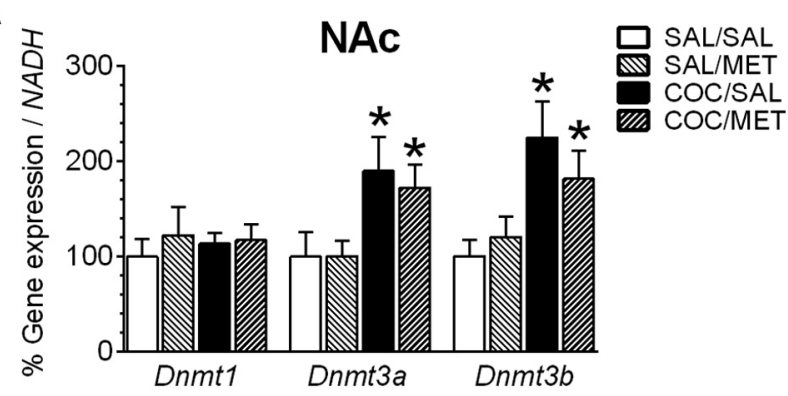

B

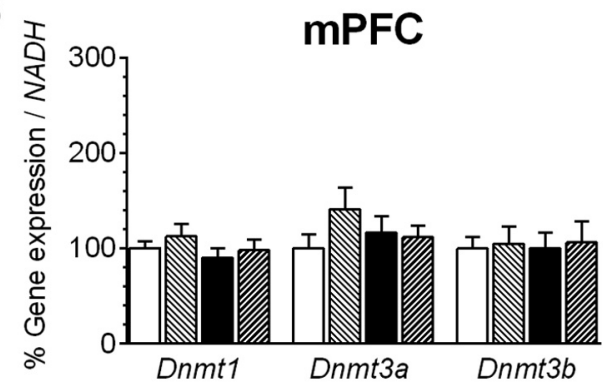

Figure 5. Dnmt1, Dnmt3a, and Dnmt3b mRNA levels assessed by RT-qPCR. $A$, In the NAc, no differences were observed in Dnmt $1 \mathrm{mRNA}$ levels. Dnmt3a and Dnmt $3 b$ were upregulated in rats that self-administered COC, independent of MET treatment. $\boldsymbol{B}$, In the MPFC, Dnmt1, Dnmt3a, and $D n m t 3 b$ levels were unchanged. Data were analyzed by two-way ANOVA and are presented as mean \pm SEM, normalized to $100 \%$ of SAL/SAL. $n=5-6$ per group. ${ }^{*} p<0.05$ compared with SAL.

administration; $F_{(1,18)}=0.3405, p=0.5668$, MET effect; $n=5-6$ per group; data not shown). Together, this suggests that Dnmt3a and Dnmt3b, but not Dnmt1, mRNA levels were upregulated specifically in the NAc after COC self-administration, but remained unaffected by MET treatment.

\section{Global DNA methylation}

Because MET is a methyl donor for DNMTs (Ross, 2003), we investigated whether MET treatment resulted in changes in global DNA methylation. Using LC-ESI MS/MS, we determined the abundance of 5'-methylcytosine in genomic DNA from the NAc and mPFC of rats after COC-primed reinstatement. In the NAc, we observed a significant reduction in global DNA methylation in rats that self-administered $\operatorname{COC}\left(F_{(1,20)}=4.412, p=\right.$ 0.048 , main effect of self-administration, $n=5-6$ per group; Fig. $6 A)$, but there was no effect of MET treatment $\left(F_{(1,20)}=0.473\right.$, $p=0.499)$. In the mPFC, global DNA methylation remained unchanged $\left(F_{(1,17)}=0.03574, p=0.8523\right.$ for self-administration effect; $F_{(1,17)}=1.353, p=0.2607$ for MET effect, $n=5-6$ per group; Fig. 6B).

\section{Regulation of c-Fos mRNA levels and c-Fos promoter methylation}

Because the immediate early gene c-Fos is induced by both acute COC exposure and during COC-primed reinstatement (Young et al., 1991; Kumar et al., 2005; Larson et al., 2010), we determined whether the blockade of COC-primed reinstatement by MET was associated with impaired c-Fos expression. We examined c-Fos mRNA levels after COC-primed reinstatement in the NAc and the mPFC. We observed a significant interaction between treatment and self-administration in both the $\operatorname{NAc}\left(F_{(1,20)}=\right.$ 4.587, $p=0.0447, n=6$ per group $)$ and the $\operatorname{mPFC}\left(F_{(1,20)}=\right.$ $4.362, p=0.0497, n=6$ per group; Fig. $7 A$ ). Bonferroni's post hoc analysis identified a significant increase in c-Fos expression be-

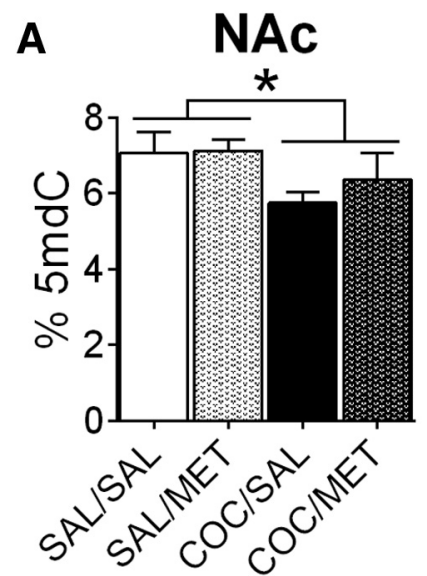

B $\quad$ MPFC

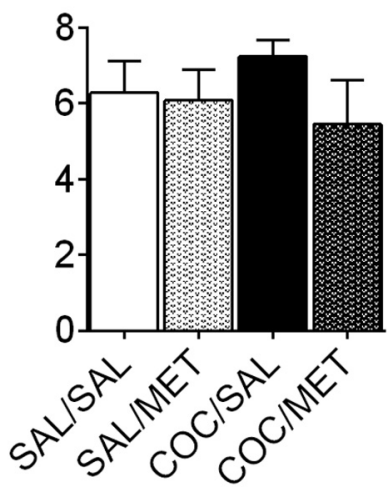

Figure 6. Global DNA methylation assessed by LC-ESI MS/MS. A, Global DNA hypomethylation was observed in the NAC as a result of $C O C$ self-administration. $\boldsymbol{B}$, No differences were observed in the MPFC. Data were analyzed by two-way ANOVA and are presented as mean \pm SEM, 5 mdC. $n=5-6$ per group. ${ }^{*} p<0.05$ compared with SAL.

tween SAL/SAL and COC/SAL in the NAc and mPFC $(t=2.305$, $p<0.05 ; t=2.514, p<0.05$, respectively). Notably, the magnitude of active responses during the COC-primed reinstatement is correlated positively with c-Fos mRNA levels in both structures, although falling short to reach significance in the NAc $\left[r^{2}=\right.$ $0.1495, \mathrm{df}=22, p=0.062$ in the NAc (Fig. $7 B) ; r^{2}=0.5158, \mathrm{df}=$ $22, p<0.0001$ in the $\mathrm{mPFC}$ (Fig. 7C)].

Figure $7 D$ shows the sequence of the c-Fos promoter that was analyzed by bisulfite sequencing. Figure $7 E$ shows the methylation state of the $12 \mathrm{CpGs}$ at the c-Fos promoter in the NAc, with the inset showing the average of all $12 \mathrm{CpG}$ dinucleotides. Consistent with mRNA levels, the c-Fos gene promoter exhibits an overall reduction of DNA methylation in the NAc after COC self-administration $\left(F_{(1,12)}=6.835, p=0.0226\right)$, which is prevented by MET treatment $\left(F_{(1,12)}=4.918, p=0.0466\right)$. This profile is observed throughout most of the individual CpG dinucleotides investigated. Of note, there was a significant effect of selfadministration at the second $\operatorname{CpG}\left(F_{(1,12)}=10.10, p=0.008\right)$ and a significant effect of MET treatment at the third $\operatorname{CpG}\left(F_{(1,12)}=6.711\right.$, $p=0.0236)$. Additionally, the ninth CpG had a significant interaction $\left(F_{(1,12)}=6.203, p=0.0284\right)$; post hoc analysis indicates that COC/SAL is significantly lower than COC/MET $(t=3.35, p<0.05)$. However, in the $\mathrm{mPFC}$, no differences in DNA methylation were observed across the $12 \mathrm{CpG}$ dinucleotides $\left(F_{(1,10)}=1.065, p=\right.$ $0.3264, n=3-4$ per group; Fig. $7 F$, inset). Nevertheless, hypermethylation of the second $\mathrm{CpG}$ was observed as a result of MET treatment $\left(F_{(1,10)}=9.267, p=0.014\right)$, regardless of COC self-administration. Together, these findings suggest that MET treatment might have reversed COC-induced DNA hypomethylation at specific CpGs to reduce c-Fos expression after COC reinstatement.

\section{Discussion}

In this study, we demonstrate that a methyl donor, MET, reduces behavioral sensitization to the locomotor-activating and drugseeking effects of chronic COC. We show that MET blocks COCinduced c-Fos activation after reinstatement in two key brain regions responsible for drug-seeking behavior and relapse: the NAc and mPFC. Furthermore, COC pretreatment induced global hypomethylation in the NAc and decreased DNA methylation at the c-Fos promoter, which was blocked by MET treatment.

Drug-induced locomotor sensitization is defined as a progressive increase in locomotor activity when a subject is exposed re- 
A

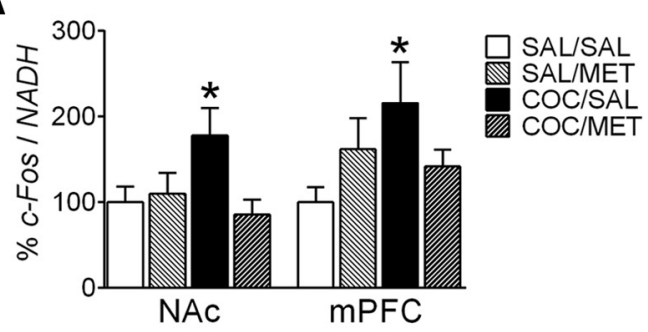

D

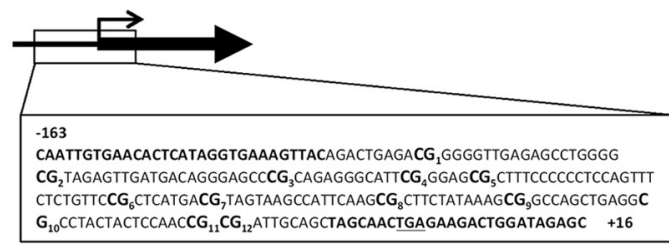

E

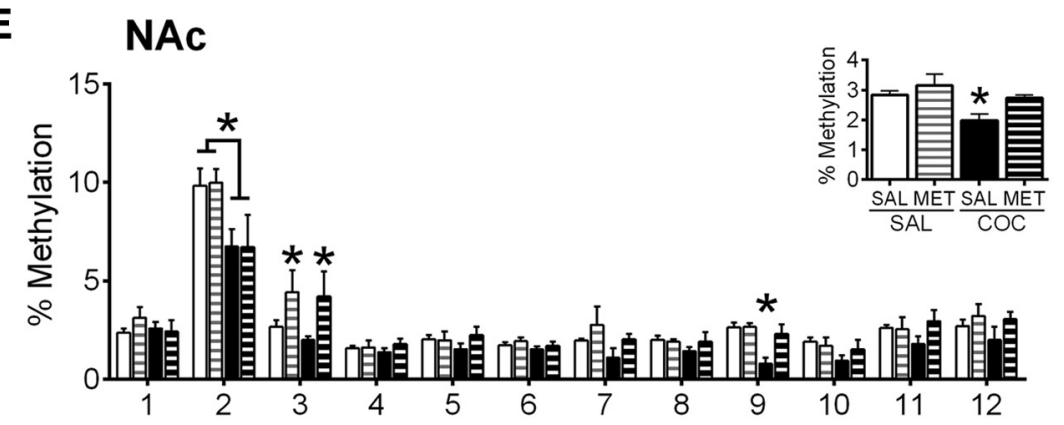

F $\quad$ MPFC

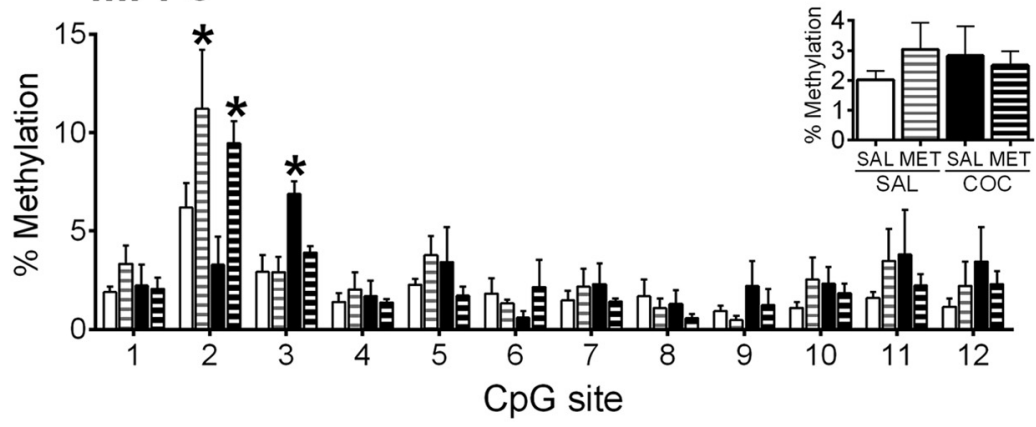

Figure 7. c-Fos expression, correlation with reinstatement, and promoter DNA methylation in the NAC and mPFC. $A, C O C-$ primed reinstatement significantly upregulated c-Fos in the NAc and $\mathrm{MPFC}$ of rats that self-administered COC and were treated with SAL, but this expression was blocked in MET-treated rats. $B, A$ trend toward a correlation was observed between the magnitude of active nose-poke responses during COC-primed reinstatement and c-Fos activation in the NAc. C, A significant positive correlation between the magnitude of active responses during COC-primed reinstatement and c-Fos in the mPFC was observed. $\boldsymbol{D}$, The sequence of the c-Fos gene promoter analyzed, with the $12 \mathrm{CpG}$ dinucleotides in bold. $\boldsymbol{E}$, Percentage of DNA methylation observed at each $\mathrm{CpG}$ dinucleotide in the NAc. Inset, Average methylation across the $12 \mathrm{CpGs}$. In the NAc, COC self-administration hypomethylates the c-Fos promoter region, whereas MET treatment returns methylation levels to that of controls. At individual CpGs, the second one is hypomethylated in $\mathrm{COC}$ self-administered rats, the third is hypermethylated in MET-treated rats, and the ninth $\mathrm{CpG}$ is significantly hypomethylated in COC self-administered rats but MET treatment returns it to control levels. $\boldsymbol{F}$, In the MPFC, no differences in average methylation was observed (inset), but there was a significant increase in methylation of the second $\mathrm{CPG}$ as a result of MET treatment. Data were analyzed by two-way ANOVA with Bonferroni's post hoc comparisons when needed and are presented as mean \pm SEM, normalized to $100 \%$ of SAL/SAL in $\boldsymbol{A} .{ }^{*} p<0.05$ compared with $\mathrm{SAL} / \mathrm{SAL}, n=5-6$ per group in $\boldsymbol{A}-\boldsymbol{C}, n=3-5$ per group in $\boldsymbol{E}$ and $\boldsymbol{F}$.

peatedly to a drug of abuse and is indicative of underlying reorganization of the mesocorticolimbic dopamine reward system (Steketee and Kalivas, 2011). MET treatment during the $10 \mathrm{~d}$ of COC exposure blocks locomotor sensitization, suggesting that MET could be preventing drug-induced neural reorganization.
Although the effects of MET on sensitization to other rewarding compounds have not been investigated, conditioned place preference studies suggest that its inhibitory effects are not generalized to food reward or morphine (Tian et al., 2012). Thus, the effects of MET and, in turn, the contribution of DNA methylation may be specific to psychostimulants (Numachi et al., 2007; Jayanthi et al., 2014) and have less of an influence on the rewarding effects of opioid compounds and natural reward. This is not surprising, because a better behavioral and pharmacological overlap is observed between opioids and natural reward than $\mathrm{COC}$ and natural reward (Kelley et al., 2002; Romieu et al., 2008). We did not observe any differences in self-administration or reinstatement of sucrose pellets, in accordance with previous findings, suggesting that MET does not have a generalized effect on other natural motivated behaviors. Our sensitization results differ from those of Anier et al. (2013), who found that SAM increased locomotor sensitization to COC. This could be attributable to differences in species, behavioral procedures, and pharmacokintetics of SAM compared with MET. MET is actively transported across the blood-brain barrier, whereas SAM is synthesized in the brain from MET (Oldendorf and Szabo, 1976), and, in fact, systemic MET administration increases brain levels of endogenous SAM more effectively than systemic SAM (Young and Shalchi, 2005).

The main goal of our study was to examine how methyl supplementation affected drug-seeking behaviors. Animal reinstatement models using cues, drugs, and stress are indispensable tools for gaining insight on human addiction and relapse because of their high construct and face validity (de Wit and Stewart, 1981; De Vries et al., 1998; Shaham et al., 2003; Epstein et al., 2006). In our hands, although rats experienced with $\mathrm{COC}$ selfadministration robustly reinstated to a priming injection of COC, MET treatment attenuated COC-seeking behavior without affecting acquisition, indicating that the blockade of COC-primed reinstatement cannot be attributed to differences in initial COC intake. Interestingly, the inhibitory effects of MET did not extend to cue-induced reinstatement, because all animals exhibited some degree of responding regardless of treatment. This could be attributable to the fact that reinstatement to cues involves recruitment of additional brain areas, including the basolateral amygdala (Di Ciano and Everitt, 2004; Ambroggi et al., 2008), that might not be affected by MET treatment. Furthermore, because all groups un- 
derwent sucrose pellet training before MET treatment, the motivational incentive to self-administer had already been established before MET treatment began, as evidenced by the fact that SAL self-administrating rats also reinstated to cues (Fig. 3D). Therefore, it is possible that MET may only have an effect prophylactically and when alterations in DNA methylation occur, as is the case with repeated COC exposure.

It is compelling that MET treatment blocked both locomotor sensitization and COC-primed reinstatement because of the shared neural substrates mediating both behaviors. Repeated exposure to COC induces molecular and structural neuroadaptations in the reward circuitry that result in COC being assigned a higher incentive salience over other motivating stimuli, contributing to the habit-forming nature of the drug (Robinson and Berridge, 1993; Nestler, 2001). A sensitized locomotor response is one behavioral manifestation of these neuroadaptations, and others have shown that selfadministration predicts subsequent sensitization (Hooks et al., 1994; Phillips and Di Ciano, 1996; Vezina, 2004) and vice versa (Piazza et al., 1990; Ferrario and Robinson, 2007). Furthermore, because sensitization is also observed in human patients (Leyton, 2007), comparing these two behavioral measures is critical to understanding the transition to addiction and the potential for relapse. It has also been shown that MET treatment attenuates conditioned place preference to COC, another commonly used index of drug reward (LaPlant et al., 2010; Tian et al., 2012). The fact that MET treatment blocks sensitization, conditioned place preference, and COC-primed reinstatement (but not cue-induced reinstatement, morphine conditioned place preference, or natural reward) suggests that DNA methylation may only mediate very specific COCinduced neuroadaptations. Identifying the exact molecular substrates for these changes will be an important task for future research.

In our hands, chronic COC pretreatment increased both Dnmt $3 a$ and Dnmt3b expression while inducing a globally hypomethylated state in the NAc (Figs. 5A, 6A, respectively). These findings raise the question of why increased Dnmt3a and $D n m+3 b$ would result in a decrease in the product of its reaction. It is possible that COC-induced Dnmt $3 a$ and Dnmt $3 b$ increases might be a counter response to the global DNA hypomethylation, and the increased availability of methyl groups via MET treatment might enable DNMTs to methylate more DNA. Furthermore, a global decrease in DNA methylation is only indicative of a net hypomethylation, but there are likely numerous genes that are also hypermethylated in response to COC and/or MET, or not affected at all. In fact, SAM and MET treatment can alter expression of a very discrete population of genes without affecting global DNA methylation (Weaver et al., 2006; Anier et al., 2013), suggesting that, for MET treatment to have any effect on transcription, it requires careful coordination of the enzymatic machinery and CpG accessibility. This is especially relevant in postmitotic cells in which DNA methylation and DNMTs are not nearly as prevalent as in dividing cells (Bird, 2002). COC induces several alterations in the epigenetic landscape, including upregulation of Dnmt3a and Dnmt3b, which allows MET to exert the behavioral and molecular effects observed in this study, and perhaps explains why no effect of MET was observed in SAL or sucrose selfadministering rats. Additionally, active DNA demethylation events come into play as well, as ten-eleven translocation 1 , which is responsible for the conversion of 5-methylcytosine to the transcriptionally permissive 5-hydroxymethylcytosine, is regulated by learning and memory processes, associated cortical and hippocampal c-Fos expression, and exposure to COC (Rudenko et al., 2013; Feng et al., 2015).

In the current study, one of the genes affected by this COCinduced hypomethylation was c-Fos, the expression of which was increased in the NAc and MPFC and correlated with reinstatement of COC-seeking behavior. This enhanced c-Fos expression is likely, as seen in human addicts, indicative of enhanced activation of the reward circuits as a result of chronic COC exposure (Bannon et al., 2014). Similarly, there is a correlation between c-Fos induction and COC-primed reinstatement of conditioned place preference in mice (Brown et al., 2010), supporting the notion that neuronal activation is critical for the reinstatement of drug-seeking behaviors. Here, MET treatment normalized the COC-induced hypomethylation observed at the c-Fos gene promoter in the NAc. This restoration in DNA methylation likely contributed to the blockade of COC-primed c-Fos induction. Furthermore, it is possible that downstream transcriptional targets of the AP-1 complex (of which c-Fos is a component, along with c-Jun) are differentially activated, which is an intriguing point to address in future studies.

In the CNS, dynamic DNA methylation changes have been observed in models of learning and memory (Levenson, 2007; Miller et al., 2008; Feng et al., 2010), synaptic plasticity (Guo et al., 2011), and responsiveness to drugs of abuse (Anier et al., 2010; LaPlant et al., 2010; Tian et al., 2012; Pol Bodetto et al., 2013; Bodetto et al., 2014). Additionally, individuals with addiction exhibit changes in DNA methylation patterns in peripheral blood and brain (Nielsen et al., 2009, 2012; Zhang et al., 2013). This is the first study to demonstrate the inhibitory effects of chronic MET on behavioral sensitization and drugseeking behavior, as well as gene expression in rats. We show that COC self-administration upregulates Dnmt3a and Dnmt3b in the NAc, regardless of MET treatment, but chronic MET treatment selectively increases methylation of the c-Fos promoter that COC exposure rendered transcriptionally permissive. At the histone level, COC alters markers of both euchromatin and heterochromatin, histone methyltransferase expression, regulation of micro-RNAs, and other posttranslational modifications (Kumar et al., 2005; Im et al., 2010; Maze et al., 2010, 2011). More research is needed to understand how histone modifications, DNA methylation, and DNA demethylation are orchestrated to regulate the behavioral and neurobiological adaptations that occur with chronic COC exposure. Relapse is the biggest hurdle to overcome on the path to recovery from addiction, and it is critical to gain a better understanding of the mechanisms behind relapse with the hopes of developing more targeted therapeutics. With these findings, we suggest additional investigation of MET as a potential treatment for COC addiction.

\section{References}

Ambroggi F, Ishikawa A, Fields HL, Nicola SM (2008) Basolateral amygdala neurons facilitate reward-seeking behavior by exciting nucleus accumbens neurons. Neuron 59:648-661. CrossRef Medline

Anier K, Malinovskaja K, Aonurm-Helm A, Zharkovsky A, Kalda A (2010) DNA methylation regulates cocaine-induced behavioral sensitization in mice. Neuropsychopharmacology 35:2450-2461. CrossRef Medline

Anier K, Zharkovsky A, Kalda A (2013) S-adenosylmethionine modifies cocaine-induced DNA methylation and increases locomotor sensitization in mice. Int J Neuropsychopharmacol 16:2053-2066. CrossRef Medline

Bannon MJ, Johnson MM, Michelhaugh SK, Hartley ZJ, Halter SD, David JA, Kapatos G, Schmidt CJ (2014) A molecular profile of cocaine abuse in- 
cludes the differential expression of genes that regulate transcription, chromatin, and dopamine cell phenotype. Neuropsychopharmacology 39:2191-2199. Medline

Bird A (2002) DNA methylation patterns and epigenetic memory. Genes Dev 16:6-21. CrossRef Medline

Bodetto SP, Romieu P, Sartori M, Tesone-Coelho C, Majchrzak M, Barbelivien A, Zwiller J, Anglard P (2014) Differential regulation of MeCP2 and PP1 in passive or voluntary administration of cocaine or food. Int J Neuropsychopharmacol 17:2031-2044. CrossRef Medline

Brami-Cherrier K, Roze E, Girault JA, Betuing S, Caboche J (2009) Role of the ERK/MSK1 signalling pathway in chromatin remodelling and brain responses to drugs of abuse. J Neurochem 108:1323-1335. CrossRef Medline

Brown RM, Short JL, Lawrence AJ (2010) Identification of brain nuclei implicated in cocaine-primed reinstatement of conditioned place preference: a behaviour dissociable from sensitization. PLoS One 5:e15889. CrossRef Medline

Day JJ, Childs D, Guzman-Karlsson MC, Kibe M, Moulden J, Song E, Tahir A, Sweatt JD (2013) DNA methylation regulates associative reward learning. Nat Neurosci 16:1445-1452. CrossRef Medline

del Castillo C, Morales L, Alguacil LF, Salas E, Garrido E, Alonso E, PérezGarcía C (2009) Proteomic analysis of the nucleus accumbens of rats with different vulnerability to cocaine addiction. Neuropharmacology 57:41-48. CrossRef Medline

De Vries TJ, Schoffelmeer AN, Binnekade R, Mulder AH, Vanderschuren LJ (1998) Drug-induced reinstatement of heroin- and cocaine-seeking behaviour following long-term extinction is associated with expression of behavioural sensitization. Eur J Neurosci 10:3565-3571. CrossRef Medline

de Wit H, Stewart J (1981) Reinstatement of cocaine-reinforced responding in the rat. Psychopharmacology (Berl) 75:134-143. CrossRef Medline

Di Ciano P, Everitt BJ (2004) Direct interactions between the basolateral amygdala and nucleus accumbens core underlie cocaine-seeking behavior by rats. J Neurosci 24:7167-7173. CrossRef Medline

Dietz DM, Dietz KC, Moore S, Ouimet CC, Kabbaj M (2008) Repeated social defeat stress-induced sensitization to the locomotor activating effects of d-amphetamine: role of individual differences. Psychopharmacology (Berl) 198:51-62. CrossRef Medline

Dong E, Nelson M, Grayson DR, Costa E, Guidotti A (2008) Clozapine and sulpiride but not haloperidol or olanzapine activate brain DNA demethylation. Proc Natl Acad Sci U S A 105:13614-13619. CrossRef Medline

Duclot F, Kabbaj M (2013) Individual differences in novelty seeking predict subsequent vulnerability to social defeat through a differential epigenetic regulation of brain-derived neurotrophic factor expression. J Neurosci 33:11048-11060. CrossRef Medline

Dyrvig M, Hansen HH, Christiansen SH, Woldbye DP, Mikkelsen JD, Lichota J (2012) Epigenetic regulation of Arc and c-Fos in the hippocampus after acute electroconvulsive stimulation in the rat. Brain Res Bull 88:507513. CrossRef Medline

Echeverry-Alzate V, Tuda-Arízcun M, Bühler KM, Santos Á, Giné E, Olmos P, Gorriti MÁ, Huertas E, Rodríguez de Fonseca F, López-Moreno JA (2012) Cocaine reverses the naltrexone-induced reduction in operant ethanol self-administration: the effects on immediate-early gene expression in the rat prefrontal cortex. Neuropharmacology 63:927-935. CrossRef Medline

Epstein DH, Preston KL, Stewart J, Shaham Y (2006) Toward a model of drug relapse: an assessment of the validity of the reinstatement procedure. Psychopharmacology (Berl) 189:1-16. CrossRef Medline

Everitt BJ, Robbins TW (2005) Neural systems of reinforcement for drug addiction: from actions to habits to compulsion. Nat Neurosci 8:14811489. CrossRef Medline

Feng J, Zhou Y, Campbell SL, Le T, Li E, Sweatt JD, Silva AJ, Fan G (2010) Dnmt1 and Dnmt3a maintain DNA methylation and regulate synaptic function in adult forebrain neurons. Nat Neurosci 13:423-430. CrossRef Medline

Feng J, Shao N, Szulwach KE, Vialou V, Huynh J, Zhong C, Le T, Ferguson D, Cahill ME, Li Y, Koo JW, Ribeiro E, Labonte B, Laitman BM, Estey D, Stockman V, Kennedy P, Couroussé T, Mensah I, Turecki G, et al. (2015) Role of Tet1 and 5-hydroxymethylcytosine in cocaine action. Nat Neurosci 18:536-544. CrossRef Medline

Ferrario CR, Robinson TE (2007) Amphetamine pretreatment accelerates the subsequent escalation of cocaine self-administration behavior. Eur Neuropsychopharmacol 17:352-357. CrossRef Medline

Foley PL, Barthel CH, Brausa HR (2002) Effect of covalently bound heparin coating on patency and biocompatibility of long-term indwelling catheters in the rat jugular vein. Comp Med 52:243-248. Medline

Goldstein RZ, Volkow ND (2002) Drug addiction and its underlying neurobiological basis: neuroimaging evidence for the involvement of the frontal cortex. Am J Psychiatry 159:1642-1652. CrossRef Medline

Graybiel AM, Moratalla R, Robertson HA (1990) Amphetamine and cocaine induce drug-specific activation of the c-fos gene in striosomematrix compartments and limbic subdivisions of the striatum. Proc Natl Acad Sci U S A 87:6912-6916. CrossRef Medline

Guo JU, Ma DK, Mo H, Ball MP, Jang MH, Bonaguidi MA, Balazer JA, Eaves HL, Xie B, Ford E, Zhang K, Ming GL, Gao Y, Song H (2011) Neuronal activity modifies the DNA methylation landscape in the adult brain. Nat Neurosci 14:1345-1351. CrossRef Medline

Hollis F, Duclot F, Gunjan A, Kabbaj M (2011) Individual differences in the effect of social defeat on anhedonia and histone acetylation in the rat hippocampus. Horm Behav 59:331-337. CrossRef Medline

Hooks MS, Duffy P, Striplin C, Kalivas PW (1994) Behavioral and neurochemical sensitization following cocaine self-administration. Psychopharmacology (Berl) 115:265-272. CrossRef Medline

Im HI, Hollander JA, Bali P, Kenny PJ (2010) MeCP2 controls BDNF expression and cocaine intake through homeostatic interactions with microRNA-212. Nat Neurosci 13:1120-1127. CrossRef Medline

Jayanthi S, McCoy MT, Chen B, Britt JP, Kourrich S, Yau HJ, Ladenheim B, Krasnova IN, Bonci A, Cadet JL (2014) Methamphetamine downregulates striatal glutamate receptors via diverse epigenetic mechanisms. Biol Psychiatry 76:47-56. CrossRef Medline

Jones PA (2012) Functions of DNA methylation: islands, start sites, gene bodies and beyond. Nat Rev Genet 13:484-492. CrossRef Medline

Kabbaj M (2006) Individual differences in vulnerability to drug abuse: the high responders/low responders model. CNS Neurol Disord Drug Targets 5:513-520. CrossRef Medline

Kalivas PW, Volkow ND (2005) The neural basis of addiction: a pathology of motivation and choice. Am J Psychiatry 162:1403-1413. CrossRef Medline

Kelley AE, Bakshi VP, Haber SN, Steininger TL, Will MJ, Zhang M (2002) Opioid modulation of taste hedonics within the ventral striatum. Physiol Behav 76:365-377. CrossRef Medline

Koob GF, Le Moal M (1997) Drug abuse: hedonic homeostatic dysregulation. Science 278:52-58. CrossRef Medline

Kumar A, Choi KH, Renthal W, Tsankova NM, Theobald DE, Truong HT, Russo SJ, Laplant Q, Sasaki TS, Whistler KN, Neve RL, Self DW, Nestler EJ (2005) Chromatin remodeling is a key mechanism underlying cocaineinduced plasticity in striatum. Neuron 48:303-314. CrossRef Medline

LaPlant Q, Vialou V, Covington HE 3rd, Dumitriu D, Feng J, Warren BL, Maze I, Dietz DM, Watts EL, Iñiguez SD, Koo JW, Mouzon E, Renthal W, Hollis F, Wang H, Noonan MA, Ren Y, Eisch AJ, Bolaños CA, Kabbaj M, et al. (2010) Dnmt3a regulates emotional behavior and spine plasticity in the nucleus accumbens. Nat Neurosci 13:11371143. CrossRef Medline

Larson EB, Akkentli F, Edwards S, Graham DL, Simmons DL, Alibhai IN, Nestler EJ, Self DW (2010) Striatal regulation of DeltaFosB, FosB, and cFos during cocaine self-administration and withdrawal. J Neurochem 115:112-122. CrossRef Medline

Levenson JM (2007) DNA (cytosine-5) methyltransferase inhibitors: a potential therapeutic agent for schizophrenia. Mol Pharmacol 71:635-637. Medline

Levenson JM, Roth TL, Lubin FD, Miller CA, Huang IC, Desai P, Malone LM, Sweatt JD (2006) Evidence that DNA (cytosine-5) methyltransferase regulates synaptic plasticity in the hippocampus. J Biol Chem 281:1576315773. CrossRef Medline

Leyton M (2007) Conditioned and sensitized responses to stimulant drugs in humans. Prog Neuropsychopharmacol Biol Psychiatry 31:1601-1613. CrossRef Medline

Malvaez M, McQuown SC, Rogge GA, Astarabadi M, Jacques V, Carreiro S, Rusche JR, Wood MA (2013) HDAC3-selective inhibitor enhances extinction of cocaine-seeking behavior in a persistent manner. Proc Natl Acad Sci U S A 110:2647-2652. CrossRef Medline

Maze I, Covington HE 3rd, Dietz DM, LaPlant Q, Renthal W, Russo SJ, Mechanic M, Mouzon E, Neve RL, Haggarty SJ, Ren Y, Sampath SC, Hurd 
YL, Greengard P, Tarakhovsky A, Schaefer A, Nestler EJ (2010) Essential role of the histone methyltransferase G9a in cocaine-induced plasticity. Science 327:213-216. CrossRef Medline

Maze I, Feng J, Wilkinson MB, Sun H, Shen L, Nestler EJ (2011) Cocaine dynamically regulates heterochromatin and repetitive element unsilencing in nucleus accumbens. Proc Natl Acad Sci U S A 108:3035-3040. CrossRef Medline

McFarland K, Kalivas PW (2001) The circuitry mediating cocaine-induced reinstatement of drug-seeking behavior. J Neurosci 21:8655-8663. Medline

Miller CA, Sweatt JD (2007) Covalent modification of DNA regulates memory formation. Neuron 53:857-869. CrossRef Medline

Miller CA, Campbell SL, Sweatt JD (2008) DNA methylation and histone acetylation work in concert to regulate memory formation and synaptic plasticity. Neurobiol Learn Mem 89:599-603. CrossRef Medline

Neisewander JL, Baker DA, Fuchs RA, Tran-Nguyen LT, Palmer A, Marshall JF (2000) Fos protein expression and cocaine-seeking behavior in rats after exposure to a cocaine self-administration environment. J Neurosci 20:798-805. Medline

Nelson ED, Kavalali ET, Monteggia LM (2008) Activity-dependent suppression of miniature neurotransmission through the regulation of DNA methylation. J Neurosci 28:395-406. CrossRef Medline

Nestler EJ (2001) Molecular basis of long-term plasticity underlying addiction. Nat Rev Neurosci 2:119-128. CrossRef Medline

Nielsen DA, Yuferov V, Hamon S, Jackson C, Ho A, Ott J, Kreek MJ (2009) Increased OPRM1 DNA methylation in lymphocytes of methadonemaintained former heroin addicts. Neuropsychopharmacology 34:867873. CrossRef Medline

Nielsen DA, Huang W, Hamon SC, Maili L, Witkin BM, Fox RG, Cunningham KA, Moeller FG (2012) Forced abstinence from cocaine selfadministration is associated with DNA methylation changes in myelin genes in the corpus callosum: a preliminary study. Front Psychiatry 3:60. Medline

Numachi Y, Shen H, Yoshida S, Fujiyama K, Toda S, Matsuoka H, Sora I, Sato M (2007) Methamphetamine alters expression of DNA methyltransferase 1 mRNA in rat brain. Neurosci Lett 414:213-217. CrossRef Medline

Oldendorf WH, Szabo J (1976) Amino acid assignment to one of three blood-brain barrier amino acid carriers. Am J Physiol 230:94-98. Medline

Paxinos G, Watson C (2006) The rat brain in stereotaxic coordinates. brain in stereotaxic coordinates. San Diego: Elsevier Science.

Phillips AG, Di Ciano P (1996) Behavioral sensitization is induced by intravenous self-administration of cocaine by rats. Psychopharmacology (Berl) 124:279-281. CrossRef Medline

Piazza PV, Deminiere JM, le Moal M, Simon H (1990) Stress- and pharmacologically-induced behavioral sensitization increases vulnerability to acquisition of amphetamine self-administration. Brain Res 514:22-26. CrossRef Medline

Pol Bodetto S, Carouge D, Fonteneau M, Dietrich JB, Zwiller J, Anglard P (2013) Cocaine represses protein phosphatase-1Cbeta through DNA methylation and Methyl-CpG Binding Protein-2 recruitment in adult rat brain. Neuropharmacology 73:31-40. CrossRef Medline

Renthal W, Kumar A, Xiao G, Wilkinson M, Covington HE 3rd, Maze I, Sikder D, Robison AJ, LaPlant Q, Dietz DM, Russo SJ, Vialou V, Chakravarty S, Kodadek TJ, Stack A, Kabbaj M, Nestler EJ (2009) Genomewide analysis of chromatin regulation by cocaine reveals a role for sirtuins. Neuron 62:335-348. CrossRef Medline

Robinson TE, Berridge KC (1993) The neural basis of drug craving: an incentive-sensitization theory of addiction. Brain Res Brain Res Rev 18: 247-291. CrossRef Medline

Robinson TE, Berridge KC (2003) Addiction. Ann Rev Psychol 54:25-53. CrossRef Medline

Robison AJ, Nestler EJ (2011) Transcriptional and epigenetic mechanisms of addiction. Nat Rev Neurosci 12:623-637. CrossRef Medline
Romieu P, Host L, Gobaille S, Sandner G, Aunis D, Zwiller J (2008) Histone deacetylase inhibitors decrease cocaine but not sucrose selfadministration in rats. J Neurosci 28:9342-9348. CrossRef Medline

Ross SA (2003) Diet and DNA methylation interactions in cancer prevention. Ann N Y Acad Sci 983:197-207. CrossRef Medline

Rudenko A, Dawlaty MM, Seo J, Cheng AW, Meng J, Le T, Faull KF, Jaenisch R, Tsai LH (2013) Tetl is critical for neuronal activityregulated gene expression and memory extinction. Neuron 79:11091122. CrossRef Medline

Sarkar A, Chachra P, Kennedy P, Pena CJ, Desouza LA, Nestler EJ, Vaidya VA (2014) Hippocampal HDAC4 contributes to postnatal fluoxetineevoked depression-like behavior. Neuropsychopharmacology 39:22212232. CrossRef Medline

Shaham Y, Shalev U, Lu L, De Wit H, Stewart J (2003) The reinstatement model of drug relapse: history, methodology and major findings. Psychopharmacology (Berl) 168:3-20. CrossRef Medline

Simpson DD, Joe GW, Fletcher BW, Hubbard RL, Anglin MD (1999) A national evaluation of treatment outcomes for cocaine dependence. Arch Gen Psychiatry 56:507-514. CrossRef Medline

Song L, James SR, Kazim L, Karpf AR (2005) Specific method for the determination of genomic DNA methylation by liquid chromatographyelectrospray ionization tandem mass spectrometry. Anal Chem 77: 504-510. CrossRef Medline

Steketee JD, Kalivas PW (2011) Drug wanting: behavioral sensitization and relapse to drug-seeking behavior. Pharmacol Rev 63:348-365. CrossRef Medline

Sun W, Rebec GV (2006) Repeated cocaine self-administration alters processing of cocaine-related information in rat prefrontal cortex. J Neurosci 26:8004-8008. CrossRef Medline

Szyf M, Weaver IC, Champagne FA, Diorio J, Meaney MJ (2005) Maternal programming of steroid receptor expression and phenotype through DNA methylation in the rat. Front Neuroendocrinol 26:139-162. CrossRef Medline

Tian W, Zhao M, Li M, Song T, Zhang M, Quan L, Li S, Sun ZS (2012) Reversal of cocaine-conditioned place preference through methyl supplementation in mice: altering global DNA methylation in the prefrontal cortex. PLoS One 7:e33435. CrossRef Medline

Tremolizzo L, Carboni G, Ruzicka WB, Mitchell CP, Sugaya I, Tueting P, Sharma R, Grayson DR, Costa E, Guidotti A (2002) An epigenetic mouse model for molecular and behavioral neuropathologies related to schizophrenia vulnerability. Proc Natl Acad Sci U S A 99:17095-17100. CrossRef Medline

Vezina P (2004) Sensitization of midbrain dopamine neuron reactivity and the self-administration of psychomotor stimulant drugs. Neurosci Biobehav Rev 27:827-839. CrossRef Medline

Weaver IC, Meaney MJ, Szyf M (2006) Maternal care effects on the hippocampal transcriptome and anxiety-mediated behaviors in the offspring that are reversible in adulthood. Proc Natl Acad Sci U S A 103:3480-3485. CrossRef Medline

Young SN, Shalchi M (2005) The effect of methionine and S-adenosylmethionine on S-adenosylmethionine levels in the rat brain. J Psychiatry Neurosci 30:44-48. Medline

Young ST, Porrino LJ, Iadarola MJ (1991) Cocaine induces striatal c-fosimmunoreactive proteins via dopaminergic D1 receptors. Proc Natl Acad Sci U S A 88:1291-1295. CrossRef Medline

Zhang H, Herman AI, Kranzler HR, Anton RF, Zhao H, Zheng W, Gelernter J (2013) Array-based profiling of DNA methylation changes associated with alcohol dependence. Alcohol Clin Exp Res 37 [Suppl 1]:E108-E115. CrossRef

Zhou R, Chen F, Chang F, Bai Y, Chen L (2013) Persistent overexpression of DNA methyltransferase 1 attenuating GABAergic inhibition in basolateral amygdala accounts for anxiety in rat offspring exposed perinatally to low-dose bisphenol A. J Psychiatr Res 47:1535-1544. CrossRef Medline 